\title{
Assessment of Loan default Trend on the Amount of Loan Granted to Farmers in Kwara State, Nigeria 1984- 2014
}

\author{
*Jatto, N.A ${ }^{1}$. Obalola, T.O. ${ }^{1}$. Shettima, B.A ${ }^{1}$, Okebiorun, E. ${ }^{1}$. Gunu, U.I. ${ }^{2}$ \\ ${ }^{1}$ Department of Agricultural economics, Usmanu Danfodiyo University Sokoto, PMB 2346 \\ ${ }^{2}$ Department of Agricultural economics and extension, Federal University Dustinma, Katsina PMB 5001
}

\begin{abstract}
This study was carried out to assess the growth trend in the amount of loan granted to farmers in the study area for the period 1984-2014. Secondary data was used and sourced from central bank of Nigeria statistical bulletin, Nigeria bureau of statistics and Kwara state bureau of statistics. The result showed that there was an acceleration in the amount of loan defaulted by farmers for the period 1984-2014 in the study area and $73 \%$ variations was noticed in the exponential time trend for the period. It was concluded that a rigorous effort to speedy the increase and availability of loan process to make more funds available should be inaugurated to increase farmers ability to purchase improved inputs so as to increase productivity in the agricultural sector as a whole and proper monitoring should be put in place.
\end{abstract}

Keywords- Loan, Default, trend, loan granted, Farmers.

\section{INTRODUCTION}

Agricultural loan involves giving out credit in cash to farmers for the purpose of farming. There is no doubt that agricultural credit is one of the fundamental ingredients for sustainable agricultural production; as such its accessibility and demand is one of the prerequisites for attaining the national goal of reducing poverty and economic development. Agricultural household models have suggested that farm credit is not only necessitated by the limitations of self-finance, but also by uncertainty pertaining to the level of output and the time lag between inputs and outputs (Kohansal and Mansoori , 2009).

A number of studies (Kohansal and Mansoori, 2009; Okarie, 2004) show that growth rate of investment in agriculture is less than other economic sectors. On this note, financing agriculture is one of the most important factors necessary for the improvement of the quality and quantity of farm harvest leading to increase in farmer's income as well as reducing poverty.

Generally, there is an acceptance of the important role of farm credit and a wide appreciation by most governments of the need for credit in agriculture. However, past trends and problems of agricultural loans are clear but future changes are uncertain. The recognition credit plays in agriculture is also fundamental to development of household food security, which can help farmers to maximize their economic potentials. Failures to recognize the extent of the consequences in which farmers access loan may be costly and can result in misguided policies and programs by the government, which may further bring about complex situation of hunger.

A lot of studies (Agnet, 2004; Asante, et al. 2011; Ewuola and Williams, 1995; Ijere, 1998; Nnadozie and Uzoigwe, 2002; Oladeebo and Oladeebo, 2008; Osuntokun, 1980 and Udoh, 2008) have noted the indispensability of credit in the process of socio-economic transformation and none of these studies assesses default trend on the amount granted to famers in Kwara state.

\section{METHODOLOGY}

Secondary data were used in the assessing the trend of loan granted over the period 1984 to 2014 and it was sourced from the central bank of Nigeria statistical bulletin, Nigeria bureau of statistics and Kwara state bureau of statistics. Trend and growth analysis is used to understand if there is a drift in growth of a variable over a period of time. In modeling time trend for this study the exponential trend or log-linear as employed by Tanko, et al. (2010); Maikasuwa and Ala, (2013) was modified and used for the analysis.

The exponential trend equation for loan default was specified as follows:

$$
\mathrm{y}_{\mathrm{t}=} e^{\beta_{0}+\beta_{1} t_{1}+u_{\mathrm{t}}}
$$

By taking the natural logarithm of both sides to form an amenable ordinary least square equation as follows:

$$
\begin{aligned}
& \ln \mathrm{y}_{\mathrm{t}}=\beta_{0}+\beta_{1} t_{1}+u_{\mathrm{t} . \ldots \ldots \ldots \ldots \ldots \ldots \ldots \ldots . .2} \\
& \text { Where: } \mathrm{Y}=\text { amount of loan defaulted } \\
& \text { " } \mathrm{t} \text { " = time trend variable } \\
& \beta_{0}=\text { Intercept of the trend equation } \\
& \beta_{1}=\text { Trend coefficient } \\
& u_{\mathrm{t}}=\text { Error term }
\end{aligned}
$$


To determine if there is acceleration, deceleration or stagnation in loan default in the study area, Quadratic equation time trend variable was fitted as follows:

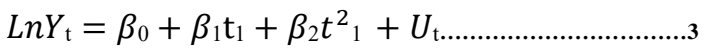

All variables as previously defined $\beta_{0}, \beta_{1,} \beta_{2}$ are parameters to be estimated. In the specification of equation above, the linear and quadratic time variable $\mathrm{t}^{2}$ allows for the possibility of determining whether there was acceleration, deceleration or stagnation in loan default in the study area during the period of 1984-2014. In determining the pattern of growth our main concern was on $\beta_{2}$ which reveals a measure of growth pattern following Oyenweanku, (2004); Tanko, et al. (2010); Maikasuwa and Ala, (2013). $\beta_{2}$ is $>0$ and statistically significant it is acceleration, if $\beta_{2}$ is $<0$ and statistically significant it is deceleration and if $\beta_{2}$ is positive or negative and not statistically significant then there is stagnation in the growth.

\section{RESULTS AND DISCUSSIONS}

The result of growth trend was done with the estimated regression coefficient of the time trend variable as in equation 3 . The data used is a secondary yearly data using an independent variable for the analysis as time lag (years of study) 1984 to 2014, while the dependent variable is amount of loan granted for the period 1984 to 2014. The adjusted $\mathrm{R}^{2}$ value of 0.68 shown in the Table 1 implies that time trend, as a variable was very important as it accounted for $68 \%$ of variations noticed in loan granted in the study area. The coefficient of the variable (0.0217) was significant suggesting that there has been an increase in loan defaulted for the period 1984-2014.

Table.1: Estimated exponential and quadratic growth trend of loan granted in the study area

\begin{tabular}{lllllll}
\hline Period & $\boldsymbol{\beta}_{\mathbf{0}}$ & $\boldsymbol{\beta}_{\mathbf{1}}$ & $\boldsymbol{\beta}_{\mathbf{2}}$ & Adjusted R & F- value & Significant level \\
\hline Exponential trend & -417.7036 & 0.0217 & & 0.68 & 7.74 & $0.00^{* * *}$ \\
& {$[56.08]$} & {$[0.028]$} & & & & \\
Quadratic trend & 32277.33 & -31.4861 & 0.0081 & 0.73 & 2.517 & $0.018^{* *}$ \\
& {$[12989.48]$} & {$[12.9927]$} & {$[0.0033]$} & & & \\
\hline
\end{tabular}

Source: field survey, 2016, []=Standard error. $* * *=1 \%, * *=5 \%$

To investigate for the existence of acceleration, deceleration or stagnation in trend of loan defaulted in the study area. The result of the quadratic equation in time trend variable was fitted in equation 3 . The result in table 1 reflected and revealed that the equation has a good fit giving the $\mathrm{R}^{2}$ value of 0.73 and the associated F-statistics at 2.517, which is statistically significant at $(\mathrm{P}<0.05)$. Table 1 also showed the slope coefficient of $t^{2}$ that the value of $\beta_{2} \quad(0.0081)$ is positive and statistically significant at $(\mathrm{P}<0.05)$ level of significance. The significant positive value is a confirmation that there is an acceleration in the amount of loan defaulted over the period 1984-2014. It therefore entails the full implementation of proper use of loan granted in order to achieve the needed demand of funds in agriculture thereby translating it to a viable sector of the economy.

\section{CONCLUSION AND RECOMMENDATION}

The study concluded that there exists a positive (increase) default trend in the loan defaulted over the years studied. Efforts should be made to increase availability of loan and make more funds available to agriculture so as to boost agricultural activities in the area which will enable farmers have access to improved seeds, farm implements etc.

\section{REFERENCES}

[1] Agnet, A. (2004, November 2,). Making farm credit work for the small-scale farmers. Retrieved from <http://www.agnet.org/library/nc/145b/>>

[2] Asante, B. O., Sefa, , V., and Sarpong, D. (2011). Determinants of small scale farmers' decision to join farmer based organizations in Ghana. African Journal of Agricultural Research, 6(10): 2273-2279.

[3] Ewuola, S., and Williams, S. (1995). Effects of Institutional and Borrower Characteristics on Loan Recovery: A Study of Ondo State Agricultural Credit Corporation. Agro search, 1(2): 109-116.

[4] Ibrahim, F., Mohammed, U., Nmadu, J., Yakubu, I., and Ibrahim, P. (2010). Forecasting and growth trends of sugar cane production: Meeting the goals of commercial Agriculture in Nigeria. 11th annual conference of nigerian asocitaion of agricultural economics (pp. 40-43). Minna, Niger state: NAAE.

[5] Ijere, M. (1998). Agricultural Credit and Economic Development, lagos: Longman.

[6] Kohansal M.R, and Mansoori, H. (2009). Factors Affecting Loan Repayment Performance of Farmers in Kharasan-Razavi Province of Iran. Conference on International Research on Food Security. Hamburg: University of Hamburg.

[7] Maikasuwa, M., and Ala, A. (2013). Trend analysis of area and productivity of sorghum in Sokoto State, 
Nigeria, 1993-2012. European Scientific Journal, 9(16): 69-75.

[8] Nnadozie, A., and Uzoigwe, J. (2002). Effectiveness of Local Sanctions on Agricultural Loan Recovery Under Community Banking in Enugu State. Journal of the Science of Agriculture, Food Technology and the Environment, 2(1): 56 - 62.

[9] Okarie, A. (2004). Major Determinant of Agricultural Smallholder Loan repayment in Developing Economy: empirical evidence from Ondo state Nigeria. The Journal of SocioEconomics, 21 (4): 223-234.

[10] Oladeebo, J. O., \& Oladeebo, O. (2008).

Determinants of loan repayment among smallholder farmers in Ogbomoso agricultural zone of Oyo State, Nigeria. Journal of Social Sciences, 17(1): 5962.

[11] Osuntokun, T. (1980). Improving The Structure of Agricultural Industry with Agricultural Credit. Ondo State Component of the 4th National Development Plan 1980-85, Akure: Ministry of Finance, Akure .

[12] Oyenweanku, C. (2004). Satgnation, acceleration and deceleration in agricultural production in Nigeria, 1970-2000. Journal of Agriculture and food Science, 2 (2): 131-140.

[13] Tanko, L., Jirgi, A., \& Igwe, K. (2010). Trend analysis of area, production and productivity of rice in Nigeria. Proceedings of the 11th Annual Conference of National Association of Agricultural Economist (NAAE) (pp. 44-48). MInna, Niger state: National Association of Agricultural Economist.

[14]Udoh, E. (2008). Estimation of loan default among beneficiaries of a state Government owned agricultural loan scheme, Nigeria. Journal of Central European Agriculture, 9(2): 343-352. 